\title{
Hunting Tourism Map of Wild Goat: Antalya District
}

\section{Halil Süel $^{1 *}$, Yasin Ünal², Serkan Özdemir', Ahmet Koca}

\begin{abstract}
The wild goat (Capra aegagrus) has a widespread area in our Turkey and is an important species in terms of hunting tourism. Every year, inventory studies are regularly carried out in all areas where these species have distributed in Turkey. Native and foreign hunters are allowed to hunting these species by given certain quota for each year and thus economic income is provided to the country. Generally, in hunting tourism, male individuals older than the age of 8 years are preferred. In this study, presence data matrix was prepared by determining the areas where the individuals aged 8 years and above, have been located according to the counts made after hunting in Antalya region in 2016. Slope, elevation, aspect, topographic position index and ruggedness variables were used for modelling by considering of the biology of wild goat. These variables were cut in local scale by using ArcGIS 10.2 software and each variable exported in ascii format. The modelling process was carried out by using MaxEnt software, which use maximum entropy approach and works with only presence data, and Random Forest method that run with both presence and absence data. The ROC value for MaxEnt was found as 0.852 and the ROC value for Random Forest method was found as 0.927 . The maps obtained by both models were intersected to determine the most suitable areas for wild goats. The hunting tourism map which shows that current and potential hunting areas of the wild goat was created by using 0.6 reference value for suitable areas on the map by using intersections of areas. This map is the first hunting tourism map of created for wild goats and very important in terms of being a guide for hunting tourism in study area.
\end{abstract}

Keywords: Antalya, Wild Goat, MaxEnt, Hunting Tourism, Habitat Suitability Modelling and Mapping, Random Forest, Wild Goat

\section{Introduction}

Wild goat (Capra aegagrus) is one of very important components of biological diversity, among the 9 species of genera Capra. It is one of the most important game animals in Turkey (Gündoğdu, 2006, Uçarlı, 2016). It is considered to be the ancestor of domesticated goats (Ahmed et al., 2015). Wild goat that is distributed in the suitable habitats in the Southeast Europe and Southwest Asia is distributed in the mountains ranging from Datça peninsula in the west of Turkey to the eastern Mediterranean in the east, Taurus and Anti-Taurus mountains and rugged mountains as high as 4000$4500 \mathrm{~m}$ in the East, Northeast and Southeast Anatolia (Gündoğdu, 2006). Located in the south of

\footnotetext{
1 Isparta University Of Applied Science, Sütçüler Prof. Dr. Hasan GÜRBÜZ Vocational School, Department of Forestry, Turkey

${ }^{2}$ Isparta University Of Applied Science, Faculty of Forestry, Department of Wildlife Ecology and Management, Turkey

* Corresponding author: halilsuel@isparta.edu.tr
}

Turkey, Antalya is an important area where the highest number of Wild goat populations in Anatolia are distributed (Gündoğdu and Oğurlu, 2009; Gündoğdu, 2006; Gönenç et al., 2018). Factors such as illegal hunting, habitat losses, enlargement of settlement areas have negative impacts on wild goat populations (Ünal et al., 2016).

In hunting tourism, it is allowed to hunt sufficient number of or abundant species in their natural habitats in a controlled way by giving priority to ecological and local values (Kozak and Bahçe, 2009). If hunting tourism requires an organization, it also provides economic contributions by creating new job opportunities especially in rural areas, as it

Citation (Atıf): Süel, H., Ünal, Y., Özdemir, S., Koca, A. (2019). Hunting Tourism Map of Wild Goat: Antalya District. Bilge International Journal of Science and Technology Research, 3 (1): 77-86. 
also needs collaboration in that organization (Willebrand, 2009). The Turkish Ministry of Agriculture and Forestry Directorate General of Nature Conservation and National Parks manages hunting tourism in Turkey in a systematic way.

The total revenue acquired in Turkey in the hunting season 2016-2017 from hunters from different countries, local hunters and illegal hunters was around 3.047.142,00 TRY. Wild goat in and around Antalya accounts for $16,4 \%$ of this revenue. In the hunting season 2017-2018, the target revenue to be generated from hunting tourism is 2,4 times higher. Wild goat accounts for $71 \%$ in that increase (URL, 2018). For the success of hunting tourism, it is essential to carry out inventory studies and scientific controls on a regular monitoring.

In Turkey, the inventory of wild goat has been taken since 2000 (Özer, 2014). These inventory studies are conducted on an annual basis in order to find out the changes in the wild goat populations, predict relative density and determine the hunting tourism quotas. The ongoing inventory studies that have gained momentum in recent years in Antalya locality are quite successful. In these studies, 7263 wild goats with 227 older than 8 years of age were recorded in 2015, 8063 with 241 older than 8 were recorded in 2016 and 8041 with 282 older than 8 were recorded in 2017 in Antalya. It is vital to identify the habitat factors in addition to the population characteristics in inventories because is extremely important to determine the suitable areas for hunting tourism (Evcin, 2018).

Modelling and mapping techniques are mainly used to determine the suitable (potential) habitat of a living organism. Modelling methods can run based on the presence and absence data (Hirzel, et al., 2006; Wisz et al., 2008; Suel, et al, 2018). As a matter of fact, such data is needed to determine the suitable areas for communities of living organisms. Besides, environmental factors in the areas where species live should also be determined to identify the potential areas of communities of living organisms (Beaumont et al., 2016; Süel et al., 2018; Şentürk et al., 2019). Only in this way, parameters that can have an impact on their distribution can be correlated and modelled (Sarhangzadeh, et al., 2013). In this study, the model was developed using both Maximum Entropy (MaxEnt) method and Random Forest method to use a different approach. We preferred to use the expression 'different 2.2. Data Collection approach' (Evans and Cushman, 2009; Grossman et al., 2010; Evans et al., 2011; Özdemir, 2018) because MaxEnt runs only on presence data while Random Forest runs on both presence and absence data. Both methods are commonly preferred in studies and yield good results. Random Forest is an algorithm that correlates presence and absence data of species with environmental factors and produces several decision trees (Breiman, 2001). It has been frequently preferred in ecology studies in recent years. MaxEnt is another method commonly used by researchers. It is known to be preferred more in studies on wild animals (Phillips et al., 2006, Hernandez et al., 2006). The main reason for it is that MaxEnt method produces a model using only the presence and absence data. This is considered to be a more accurate approach in studies conducted on moving communities of living organisms because there is ambiguity regarding the precision of the absence data obtained about the species in the sampling areas (Baldwin, 2009). Due to the abovementioned points, the purpose of this study was to develop the first wild goat hunting tourism map of Turkey by drafting model maps using both methods and then combining those models.

\section{Materials and Methods}

\subsection{Study Area}

The study area is Antalya (Figure 1). Antalya was selected as study area due to successful inventory studies on wild goat and study area has a high potential of species and has a high annual hunting quota.

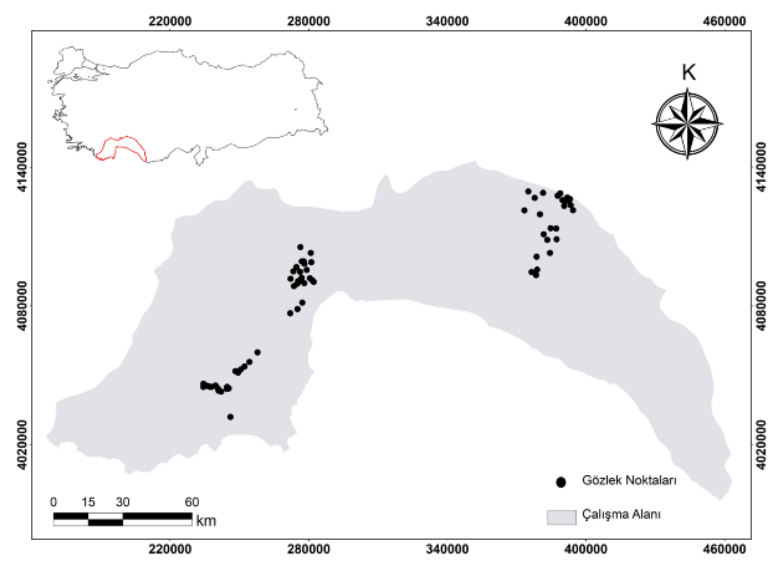

Figure 1: Location map of study area

In this research, it was found that wild goat individuals aged 8 and older were present at 55 
points and absent at 29 points through direct observation at 84 observation points in Antalya during the wild goat counts in January-February 2016. As individual animals aged 8 and older are important for hunting tourism, the data of these points was used.

\subsection{Environmental Parameters}

All environmental variables were composed using ArcMap (v. 10.2) software. In this context, contour lines of the study area were taken as the basis to develop the Digital Elevation Model (DEM). Topographic position index (Jennes, 2016), ruggedness (Riley et al., 1999), slope, elevation and aspect variables generated by DEM were used for modelling.

\subsection{Maximum Entropy Algorithm (MaxEnt)}

MaxEnt method that is based on the measurement value of a random variable and of an associated uncertainty for the analysis of habitat suitability (Elith et al., 2010) was used (Mert and Kıraç, 2017; Tekin et al., 2018). 10\% of the data used in modelling was used for test evaluation and the remaining data was used for training assessment while the model was validated through crossvalidation (Phillips et al., 2006, Oruç, et al. 2017). The success of the resulting model was decided according to the AUC or ROC value. When these values ranged from 0,5 to 1 and the value is closer to 1 , it meant that the model was successful (Baldwin, 2009).

\subsection{Random Forest Method}

Random Forest method is a machine learning algorithm that runs by generating a number of decision trees. While generating the decision trees with this method, each decision tree was obtained by selecting samples from the data sets with the bootstrap technique. Moreover, a variable is randomly selected in the designated number from all variables at every node. The trees that are created are not pruned. Therefore, it is a frequently preferred machine learning algorithm as most of the time it generates scientific results. In this study, the number of the variables to be selected randomly at each node during modelling was designated to be 3 which was the square root of the total number of variables. AUC value was used to measure the success of the model. Modelling was performed using the "randomForest" package in the R-Studio software (Özdemir, 2018; Özdemir and Ulusan, 2018).

\section{Results}

Successful models for the hunting ground for wild goat were obtained using both MaxEnt method and random forest method. The environmental variables which were slope, aspect, elevation, ruggedness and topographic position index were compared with the models obtained through two different methods. Furthermore, the resulting models were mapped and the maps were overlapped so that their intersections were located. Those maps with a pixel value of 0,6 (Mert, et al., 2016) were used to create the distribution map for hunting tourism potential.

\subsection{Model Accuracy and Prediction Performance for MaxEnt}

A successful and valid model with training and test AUC values of 0.851 and 0722 , respectively, was developed through the MaxEnt approach (Figure 2).

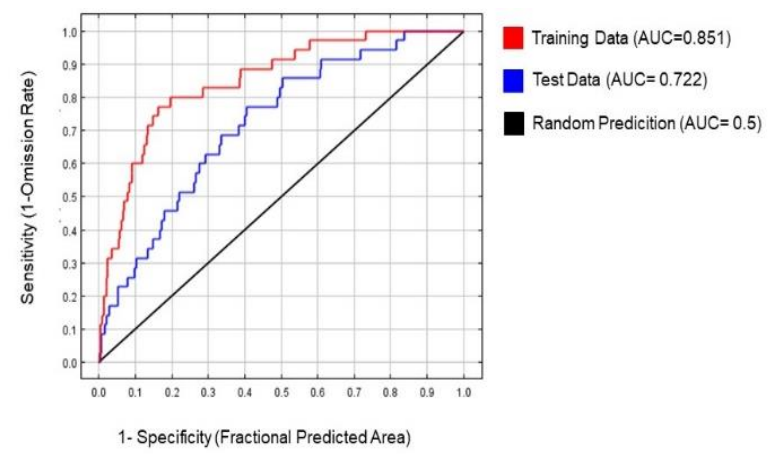

Figure 2: ROC curves of habitat suitability model generated for wild goat using MaxEnt

The variables in the model and jackknife graphic that showed their contributions are presented in Figure 3. Ruggedness had the highest contribution to the model. If removed from the model, topographic position index would have the highest positive impact on the model gain. 


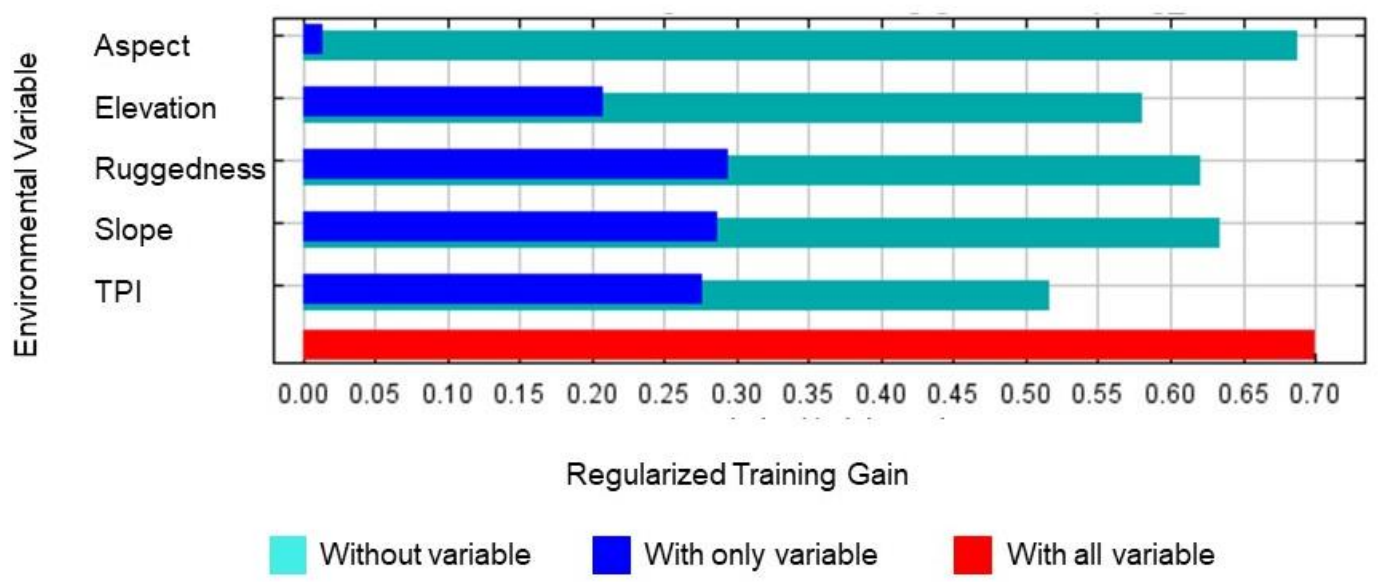

Figure 3: Jackknife Graph of the Variables that shaped the wild goat Habitat Suitability Model

Response curves of the variables create the MaxEnt model are given in Figure 4. Accordingly, it was found that this species preferred all aspects in general, had a positive relationship up to $1200 \mathrm{~m}$ depending on elevation and a negative relationship at higher elevations. It was also found that it preferred rugged habitats and slopes up to moderately sloped areas. As regards the topographic position, it kept away from the valley bottoms.

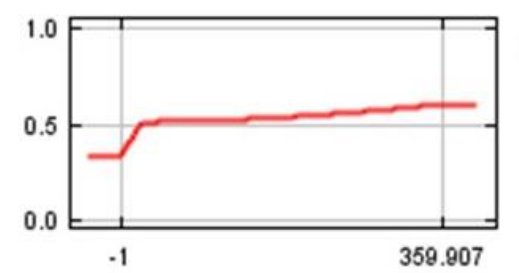

A
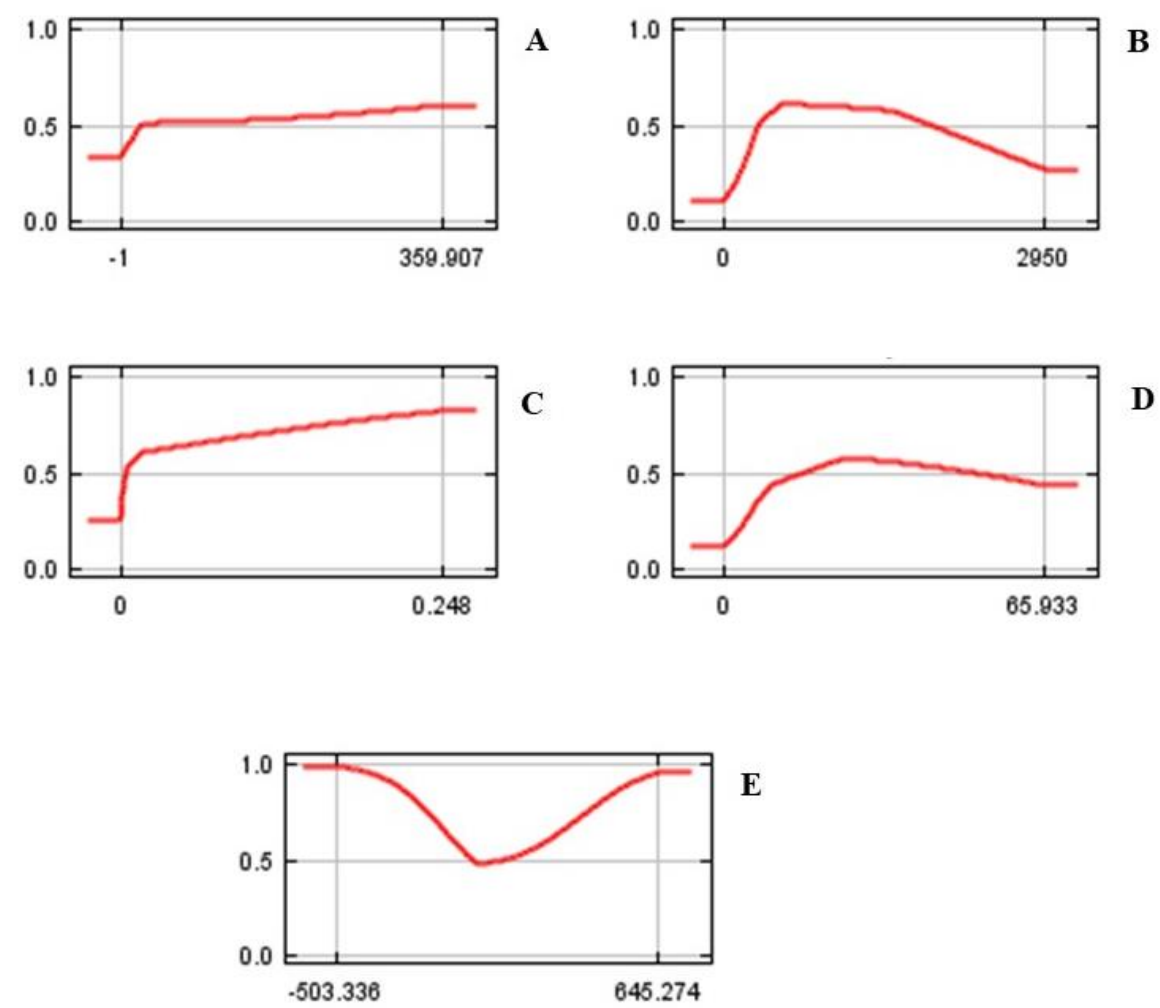

Figure 4. Response curves of the variables in the MaxEnt model (A:Aspect, B:Elevation, C: Ruggedness, D: Slope and E: Topographic Position Index) 


\subsection{Model Accuracy and Prediction Performance for Random Forest}

The ntree function created with the Random Forest method was selected as 500. The bootstrap error convergence of the trees created are presented in Figure 5. The AUC value of 0.927 of the model had a high explanatory power similar to the one in the MaxEnt approach.

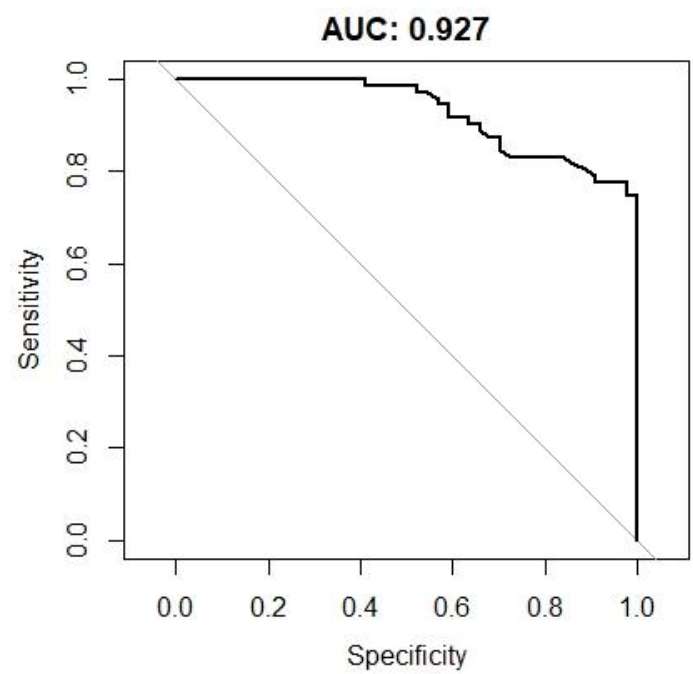

Figure 5. ROC value of the habitat suitability model created for wild goat using Random Forest method.

The significance of the variable in the model created with the Random Forest method is shown in Figure 6. The variables that contributed to the Model were found to be Aspect, Elevation, TPI,
Slope and Ruggedness, respectively, according to their contribution level.

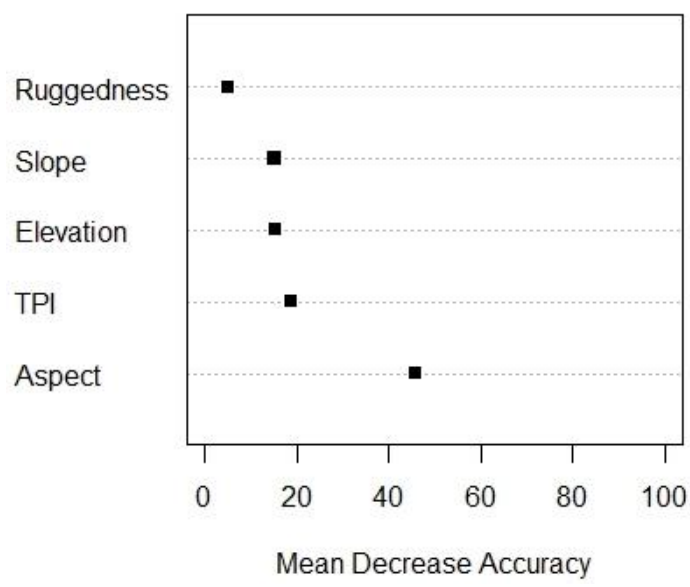

Figure 6. Importance of variables used for the Random Forest model

\subsection{Habitat Suitability Maps}

The values ranged from 0 to 1 in the potential distribution map of the models. The red spots on the maps represent the most suitable areas for wild goat hunting tourism. Blue spots represent the unsuitable areas. The combined map that was created with the distribution map generated using both algorithms (MaxEnt, Random Forest) and their intersections is shown in Figure 7. 


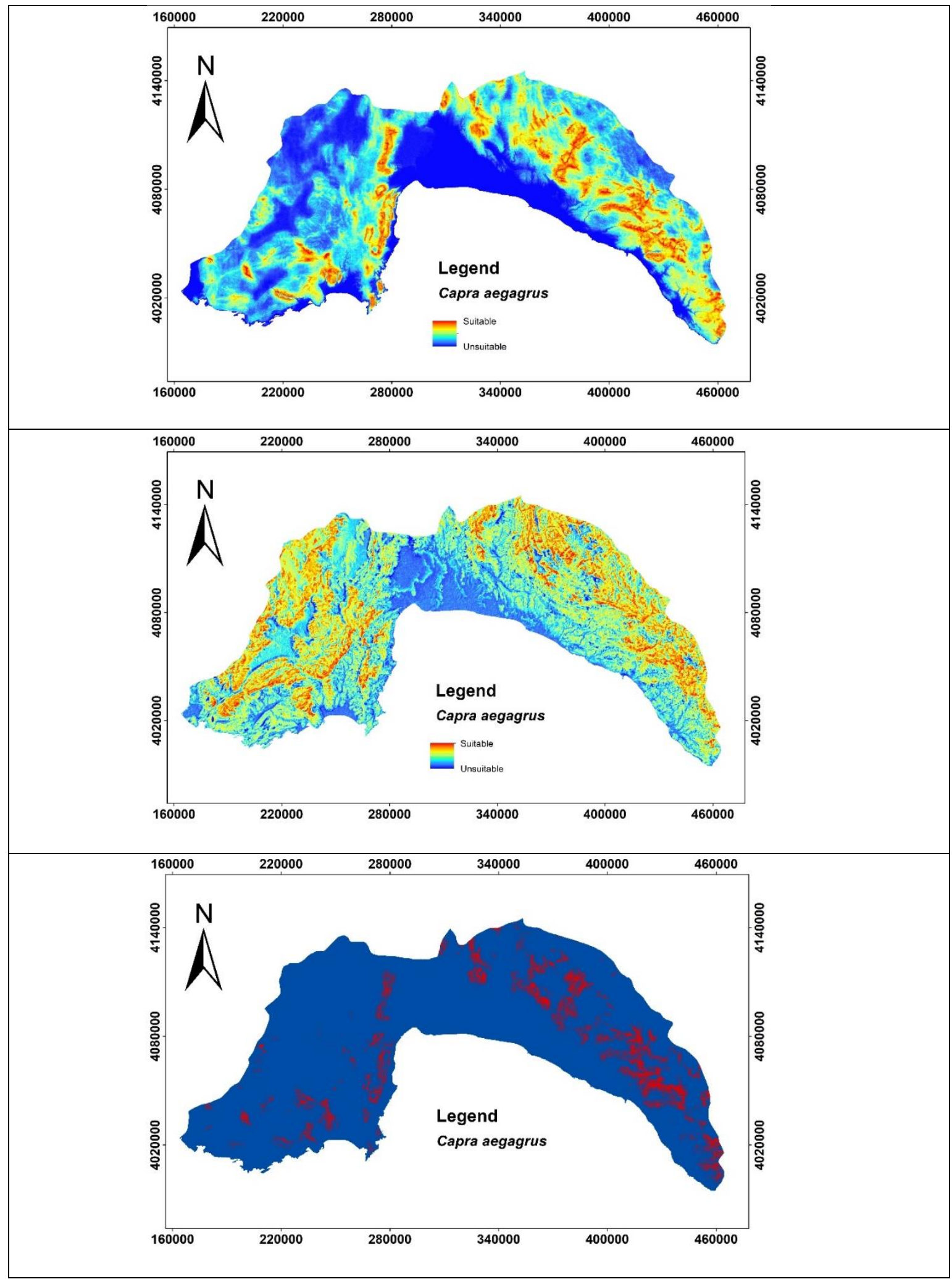

Figure 7. Potential distribution maps of Capra aegragrus (a: MaxEnt model, b: Random Forest model, c: Intersection of $\mathrm{a}$ and $\mathrm{b}$ with 0.60 reference value) 


\section{Conclusions}

In Turkey, there are studies that use modelling and mapping for alternative forms of tourism. In this study, models were developed for wild goat in Antalya province with MaxEnt and Random Forest methods. Potential distribution maps of the models were generated and the optimal hunting tourism potential map was created by overlapping the maps generated through both methods (reference value for suitable areas: 0.6) (Mert, et al., 2016).

For example, Morovati et al., (2014) reported that wild goat was associated with slope, aspect and elevation. Sarhangzadeh et al., (2013) found that the distribution of wild goat on slope, aspect, elevation and rocky areas and its habitat choice were seasonal. In our research, we also found similar results. It was observed that topographic position index, aspect, ruggedness and elevation that were the variables used for the maps created with both methods in our study (MaxEnt and Random Forest) had a direct impact on the distribution of wild goat. Therefore, excessively rugged areas, moderately sloped areas, north aspects and elevation of around $1200 \mathrm{~m}$ seem to be the suitable areas for the hunting tourism of wild goat. Özkan et al. (2012) reported that the Mediterranean Region and the Lakes Region in Turkey had high potential values. Hunting tourism seems to be one of the potentials. Particularly Antalya province where the study was conducted is remarkable as regards its hunting animal potential. However, there are also some threats to this potential in that region. Recently, it was understood from the interviews held with local people during the inventory work in the study area that the most important factor that led to the death of wild goat was illegal hunting because hundreds of wild goats were hunted illegally every year. In a study conducted by Gündoğdu (2006) in Yazılıkaya Potential Wildlife Development Area which is $100 \mathrm{~km}$ north of Antalya, he found that the revenues to be generated from hunting tourism were far below that it had to be due to uncontrolled and illegal hunting. Therefore, Oğurlu and Ünal (2011) argued that a Conservation Model should be developed by the Village Legal Entity and field watchmen/guides who can check the field and know the area and local people should be employed to solve the issue of illegal hunting with a view to generating adequate revenues from hunting tourism. In this model, it is thought that it will contribute significantly to the maximum success of conservation-control mechanism if the conservators have a wild goat hunting tourism map.

The Ministry of Agriculture and Forestry Directorate General of Nature Conservation and National Parks carries out inventory studies every year in the Wildlife Development Areas (WDA) for wild goat which is one of the primary wild animal species in hunting tourism in Turkey. Universities and NGOs support these studies on a voluntary basis. Inventories help increasing populations in the relevant WDA, hunting tourism quota and the quantity and quality of trophy. An important point these resources should be protected together with their habitat to maintain the sustainability of hunting tourism. Conservation will result as an increasein populations; therefore, potential habitats should be identified in advance and included in hunting management plans. As mentioned above, potential habitats can only be identified by establishing the correlations between the species and the environmental variables. Hunting activities should be concentrated in these areas, through which it is predicted that hunting success will be directly affected.

This study identified the areas where 8 year-old and older individuals used in hunting tourism were distributed and their potentials. Any hunter can easily find the most suitable hunting areas by just checking this map. This will contribute to the availability of individuals according to the quota designated for hunting tourism and success of hunting.

In conclusion, it is clear that all kinds of hunting tourism activities contribute significantly to the Turkish economy and management of natural resources. It is important to conduct further studies in this field.

\section{Acknowledgements}

We would like to thank the $6^{\text {th }}$ Regional Directorate of the Ministry of Agriculture and Forestry for its contribution to this study. This study titled "Hunting Tourism Map of Wild Goat: Antalya District" was published as a paper in International Multidisciplinary Congress of Eurasia (Imcofe 2018 / Barcelona). 


\section{References}

Ahmed, A., Vlasseva, V., Kitanova, S., Genov, P. (2015). Bezoar Wild Goat (Capra Aegagrus Erxleben, 1777) - history and opportunities for development of the species in Bulgaria, Annuaire de l'Université de Sofia “St. Kliment Ohridski" Faculte de Biologie First National Conference of Reintroduction of Conservation-reliant Species, Sofia 2015 University Press 2016, pp. 171-175.

Baldwin, R.A. (2009). Use of maximum entropy modeling in wildlife research. Entropy, 11(4), 854-866.

Breiman, L. (2001). Random forests. Machine learning, 45(1), 5-32.

Elith, J., Graham, C.H., Anderson, R.P., Dudik, M., Ferrier, S., Guisan, A., Hijmans, R.J., Huettmann, F., Leathwick, J.R., Lehmann, A., Li, J., Lohmann, L.G., Loiselle, B.A., Manion, G., Moritz, C., Nakamura, M., Nakazawa, Y., Overton, J.McC., Peterson, A.T., Phillips, S.J., Richardson, K.S., Scachetti-Pereira, R., Schapire, R.E., Soberon, J., Williams, S., Wisz, M.S., Zimmermann, N.E. (2006). Novel methods improve prediction of species distributions from occurrence data, Ecography, 29(2), $129-151$

Evans, J. S., Cushman, S. A. (2009). Gradient modeling of conifer species using random forests. Landscape Ecology, 24(5), 673683.

Evcin, Ö. (2018). Kastamonu ve Sinop'ta karacanın (Capreolus capreolus) popülasyon ekolojisi / Population ecology of roe deer (Capreolus capreolus) in Kastamonu and Sinop. Kastamonu Üniversitesi, Fen Bilimleri Enstitüsü, Doktora Tezi, Artvin.

Gönenç, B., Emir, H., Iajob, O. (2018). Digestive tract helminths of Turkish ibex (Capra aegagrus aegagrus Erxleben, 1877), Ankara Üniv Vet Fak Derg, 65, 247-251.

Gündoğdu E, Oğurlu İ. (2009). Population ecology of wild goat Capra Aegagrus Erxleben 1777 in Isparta, Turkey. J Anim Vet Adv, 8, 2318-2324.

Gündoğdu E. (2006). Population Ecology of the Wild Goat (Capra aegagrus Erxleben 1777) in Isparta Region (Phd Thesis), SDU
Graduate School of Natural and Applied Sciences, Department of Forest Engineering, Isparta.

Hernandez, P.A., Graham, C.H., Master, L.L., Albert, D.L. (2006). The effect of sample size and species characteristics on performance of different species distribution modeling methods. Ecography, 29(5), 773-785.

Hirzel, A. H., Le Lay, G., Helfer, V., Randin, C., \& Guisan, A. (2006). Evaluating the ability of habitat suitability models to predict species presences. Ecological Modelling, 199(2), 142-152.

Jaynes, E.T. (1957). Information theory and statistical mechanics. Physical Review, 106(4), 620.

Jenness, J. (2006). Topographic Position Index (tpi_jen. avx) Extension for ArcView 3. x version 1.2. Jenness Enterprises, Flagstaff, AZ.

Kozak, M. A., Bahçe, S. (2009). Özel İlgi Turizmi. Ankara, Detay Yayıncilık.

Mert, A., Kıraç, A., 2017. Isparta-Sütçüler Yöresinde Anatololacerta danfordi (Günter, 1876)'nin Habitat Uygunluk Haritalamas1. Bilge International Journal of Science and Technology Research 1(1), 16-22.

Mert, A., Özkan, K., Şentürk, Ö., Negiz, M.G. (2016). Changing the Potential Distribution of Turkey Oak (Quercus cerris L.) under Climate Change in Turkey, Pol. J. Environ. Stud. Vol. 25, No. 4 (2016), 1-6, DOI: $10.15244 /$ pjoes/62230.

Morovati, M., Karami, M., Kaboli, M. (2014). Desirable areas and effective environmental factors of wild goat habitat (Capra aegagrus). International Journal of Environmental Research, 8(4), 1031-1040.

Oğurlu, İ., Ünal, Y. (2011). Yaban hayatı çalışmalarında üniversite, yerel halk ve kamu işbirliği: Isparta Aksu örnek avlağında yaban domuzu envanteri. Turkish Journal of Forestry, 12(1), 7-12.

Oruç, M.S., Mert, A., Özdemir, İ. (2017). Eskişehir Çatacık Yöresinde, Çevresel Değişkenler Kullanılarak Kızılgeyik İçin (Cervus elaphus L.) Habitat Uygunluğunun Modellenmesi. Bilge International Journal of Science and Technology Research, 1 (2): 135- 142. 
Özdemir, S. (2018). Random Forest Yöntemi kullanılarak potansiyel dağılım modellemesi ve haritalamas: Yukarıgökdere Yöresi örneği. Turkish Journal of Forestry, 19(1): 51-56.

Özdemir, S., Ulusan, M.D. (2018). Modelling Potential Distribution of Turkish Oregano (Origanum onites L.) using Random Forest Method in Ovac1k Mountain District. International Conference on Science and Technology (September, 5-9), 147, Kosovo.

Özer, M. (2014). Büyük memeli av hayvanı sayım teknikleri ve ülkemizdeki populasyonlarının durumu. Ankara: TMMOB Orman Mühendisleri Odas1 Meslek Mensupluğu Hazırlama Eğitimi Ders Notları, 1-16.

Özkan, K., Negiz, M.G., Sentürk, Ö., Kandemir, H. (2012). Göller bölgesi'ndeki bazı önemli rekreasyon alanları ve onların ekolojik özellikleri, I. Rekreasyon Araştırmaları Kongresi 2012, Bildiri Kitab1, 12-15 Nisan 2012, 587-596,Detay Yayınc1lik, KemerAntalya.

Phillips, S.J., Anderson, R.P., ve Schapire, R.E. (2006). Maximum entropy modeling of species geographic distributions.

Riley, S.J., DeGloria, S.D., Elliot, R. (1999). A Terrain Ruggedness Index That Quantifies Topographic Heterogeneity. Intermountain Journal of Sciences, 5(1-4):23-27. Ecological Modelling, 190(3), 231-259.

Sarhangzadeh, J., Yavari, A. R., Hemami, M. R., Jafari, H. R., Shams-Esfandabad, B. (2013). Habitat suitability modeling for wild goat (Capra aegagrus) in a mountainous arid area, central Iran. Caspian Journal of Environmental Sciences, 11(1), 41-51.

Shannon, C.E. (1948). A mathematical theory of communication. The Bell System Technical Journal, 27, 379-423, 623-656.

Süel, H. (2014). Isparta-Sütçüler yöresinde av türlerinin habitat uygunluk modellemesi, SDÜ Fen Bilimleri Enstitüsü Doktora Tezi, 165 p., Isparta.

Suel, H., Senturk, Ö., Mert, A., Özdemir, S., Yalçınkaya, B. (2018). Habitat Suitability Modeling and Mapping, IMCOFE V. International Multidisciplinary Congress of
Eurasia, 21 May 2018, Edt., Kahramanova, K., pp. 536,549, Barcelona, Spain.

Tekin, S., Yalçınkaya, B., Acarer, A., Mert, A. (2018). A research on usage possibilities of satellite data in wildlife: Modeling habitat suitability of Roe deer (Capreolus capreolus L.) with MaxEnt. Bilge International Journal of Science and Technology Research, 2 (2): 147-156.

Ünal, Y., Koca, A., Yelsiz, M. Ş., Bal, O. K. (2016). Wild Goat (Capra aegagrus Erxleben, 1777) population inventory in Turkey. Isparta Region Example (20082013). Caucasus Ecosystem: Past, Present and Future (80 years of Zoological Investigations of the Caucasus, International Scientific Conference, 23-24 November 2016. 564-569p. Baku.

URL, (2018). http://t24.com.tr/haber/2017yilinda-kara-avciligi-kanununu-ihlalden-6bin-912-kisiye-5-milyon-309-bin-lira-paracezasi-kesildi,562543 adresinden 15.05.2018 tarihinde alınmıştır.

Willebrand, T. (2009). Promoting hunting tourism in north Sweden: opinions of local hunters. European journal of wildlife research, 55(3), 209.

Wisz, M.S., Hijmans, R., Li, J., Peterson, A.T., Graham, C., Guisan, A. (2008). Effects of sample size on the performance of species distribution models. Diversity and Distributions, 14(5), 763-773.

Wisz, M.S., Hijmans, R., Li, J., Peterson, A.T., Graham, C., Guisan, A. (2008). Effects of sample size on the performance of species distribution models. Diversity and Distributions, 14(5),763-773.). Implications of Landslide Typology and Predisposing Factor Combinations for Probabilistic Landslide Susceptibility Models: A Case Study in Lajedo Parish (Flores Island, Azores-Portugal). Geosciences, 8(5), doi:UNSP 153 10.3390/geosciences8050153.

Şenel, M., Bedi, Y., Usta M. (2016). 1/100:000 Ölçekli Jeoloji Haritaları Serisi Silifke P-28 Paftası Jeoloji Etütkleri Dairesi No:223 Ss.29 Maden Tetkik Ve Arama Genel Müdürlüğü, Ankara-Türkiye. 
Taga, H., Zorlu, K., (2017). Dik Yamaçlardaki Kaya Düşme Tehlikesinin Değerlendirilmesi: Ermenek (Karaman, Türkiye). Hacettepe Üniversitesi Yerbilimleri Uygulama ve Araştırma Merkezi Bülteni, 2017, 38(2), 161-178.

Tekin, S., Çan, T. (2018). Effects of Landslide Sampling Strategies on the Prediction Skill of Landslide Susceptibility Modelings. Journal of the Indian Society of Remote Sensing, 46(8), 1273-1283, doi:10.1007/s12524-018-0800-4.

Tekin, S., Çan, T., (2015a). Bulanık Mantık ve Yapay Sinir Aği Yöntemleri İle Heyelan Duyarllılık Değerlendirmesi, 68. Türkiye Jeoloji Kurultayı, Bildiri Özleri Kitabı, s. 112-114. Ankara.
Tekin, S., Çan, T., (2015b). "Ermenek Havzasının Yapay Sinir Ağları Yöntemi İle Heyelan Duyarlılık Değerlendirmesi”. Doğu Anadolu Jeoloji Sempozyumu 7-11 Eylül 2015, bildiri özleri kitabı, ss. 114-115. YYU-Van/Türkiye.

Tekin, S., Çan, T., Mazman, T., duman, T.Y., (2015), Doğu Akdeniz Bölgesinin Yapay Sinir Ağları Yöntemi ile Heyelan Duyarlılık Değerlendirmesi, MÜHJEO'2015: Ulusal Mühendislik Jeolojisi Sempozyumu, 3-5 Eylül 2015, KTÜ, Trabzon.

Uçarlı, Y., 2016. Çoruh Vadisi ve Verçenik Dağı yaban hayatı geliştirme sahalarındaki barajların yaban keçisi üzerine etkileri. Artvin Çoruh Üniversitesi, Fen Bilimleri Enstitüsü, Doktora Tezi, Artvin. 